\begin{tabular}{|rr} 
Bulletin of the Chemists and Technologists \\
Of Bosnia and Herzegovina
\end{tabular}

\title{
Phenolic Composition, Antioxidant and Antimicrobial Activity of Cotoneaster Medik. Species from Bosnia and Herzegovina
}

\author{
Mahmutović-Dizdarević, I. ${ }^{a}$, Dizdar, M., Čulum, D. ${ }^{\text {, }}$, Vidic, D. ${ }^{\text {, }}$, Dahija, S. ${ }^{\text {a }}$, \\ Jerković-Mujkić, A. ${ }^{\text {, Bešta-Gajević, R. }}{ }^{a}$ \\ ${ }^{a}$ Department of Biology, Faculty of Science, University of Sarajevo, Zmaja od Bosne 33-35, Sarajevo, B\&H \\ ${ }^{b}$ Department of Chemistry, Faculty of Science, University of Sarajevo, Zmaja od Bosne 33-35, Sarajevo, B\&H
}

Article info

Received: 18/06/2019

Accepted: 07/10/2019

Keywords:

Bioactivity

Cotoneaster integerrimus Medik.

Cotoneaster tomentosus (Aiton) Lindl.

Cotoneaster horizontalis Decne

\author{
*Corresponding author: \\ Irma Mahmutović-Dizdarević \\ E-mail: irma.contagium@gmail.com \\ Phone: 00 387-61-133-977
}

\begin{abstract}
Although the genus Cotoneaster Medik. includes mainly ornamental species, there are some data regarding its biological activity. The purpose of this study was to analyze the content of phenolic compounds, acetylcholinesterase inhibition, antioxidant and antimicrobial activity of methanolic extracts of leaf and bark of C. integerrimus Medik., C. tomentosus (Aiton) Lindl. and C. horizontalis Decne. The $C$. tomentosus leaf extract exhibited the highest content of total phenols (135.86 mg GAE/g) and flavonoids (18.17 mgQE/g), and also the most potent antioxidant activity against nonbiogenic free radicals, while the highest inhibition of acetylcholinesterase had the leaf extract of $C$. horizontalis ( $\mathrm{IC}_{50} 0.34 \mathrm{mg} / \mathrm{mL}$ ). All extracts showed a significant level of antibacterial and antifungal activity against tested microbial strains. The largest inhibition zones were observed against Candida albicans treated with C. integerrimus leaf extract ( $30.50 \pm 0.50 \mathrm{~mm}$ ). Furthermore, C. integerrimus extract was the most effective in the majority of bacterial strains tested. The results indicated that methanolic extracts of the investigated Cotoneaster species have promising bioactive and therapeutic potentials.
\end{abstract}

\section{INTRODUCTION}

Many medicinal plants are so far recognized as valuable resources of natural antimicrobial compounds, and wide range of phytochemicals in plants have potential to inhibit microbial pathogens (Romero et al., 2005). These biomolecules are mainly secondary metabolites, such as: alkaloids, glycosides, terpenoids, saponins, steroids, flavonoids, tannins, quinones and coumarins (Das, Tiwari and Shrivastava, 2010). Despite the fact that numerous plant species have been used in traditional medicine for centuries to treat infectious diseases, their bioactive compounds need to be determined. Furthermore, discovering the new potential antimicrobial resources from plants overcomes the domain of folk medicine and could have a promising impact in modern phytopharmacy, especially in the case of multidrugresistant (MDR) pathogens (Agarwal et al., 2016). Usage of plant products have significantly increased in last decades, since synthetically derived compounds are often expensive, and could have unfavorable health effects (Uysal et al., 2016). The genus Cotoneaster Medik. belongs to the family Rosaceae, and in Bosnia and Herzegovina is represented by two species: $C$. integerrimus Medik. and C. tomentosus (Aiton) Lindl. (Beck-Mannagetta, 1927; Euro+Med PlantBase). Many Cotoneaster species are cultivated in Europe as ornamental plants in urban areas (Fryer and Hylm, 2009), and $C$. horizontalis Decne. is one of the most famous cultivars widely used in B\&H. Data suggest that Cotoneaster species have traditionally been used for medicinal purposes. Cotoneaster racemiflorus (Desf.) $\mathrm{K}$. Koch is known as an aperient, expectorant and stomachic, as well as a treatment for reducing jaundice (Chopra and Nayar, 1956). Khan et al. (2008) isolated two bioactive compounds from this species, and these new aromatic esters were named cotonoates A and B. Furthermore, specific bioactive compounds are recognized in other Cotoneaster species, e.g. phenolic glycosides in C. orbicularis Schltdl. (El-Mousallamy et al., 2000). Phytoalexin named cotonefuran with bactericidal activity was primarily isolated from $C$. 
lacteus W. W. Sm. (Burden et al., 1984), and about a decade later, confirmed as well in C. acutifolius Turcz., with prominent antifungal properties (Kokubun et al., 1995). Antimicrobial effects have also been reported in C. nummularius Fisch. \& C. A. Mey. (Zengin et al., 2014) and C. nummularioides Pojark. (Kanaani, Sani, and Yaghooti, 2015; Siami, Sani and Branch, 2016). Data on the chemical composition and antimicrobial activity of investigated Cotoneaster species are scarce (Mohamed et al., 2012; Sokkar et al., 2013; Sytar et al., 2016; Uysal et al., 2016), or non-existent. The aim of this study was to investigate: phenolic compounds content, acetylcholinesterase (AChE) inhibition, antioxidant and antimicrobial activity of three Cotoneaster species: $C$. integerrimus Medik., C. tomentosus (Aiton) Lindl. and C. horizontalis Decne.

\section{EXPERIMENTAL}

\section{Chemicals and plant material}

All reagents and solvents were purchased commercially and were of analytical grade. The plant material (leaves and bark) of three Cotoneaster species: C. integerrimus, C. tomentosus, and C. horizontalis was collected in September 2017. Ten individuals of each species were analyzed. Cotoneaster integerrimus and C. tomentosus were collected on Mountain Ozren near Sarajevo, Bosnia and Herzegovina, while $C$. horizontalis was sampled in urban Sarajevo area. Determination of plant material was carried out in Laboratory for Plant Systematics, Department of Biology, Faculty of Science, University of Sarajevo. Voucher specimens were deposited in the Herbarium of the Faculty of Science, University of Sarajevo. Separation of plant material into leaves and bark was performed, and such separated plant material was dried in dark in ventilated room at the ambient temperature.

\section{Preparation of extracts}

Dried plant material was grounded to fine dust and then extracted for 24 hours using $80 \%$ methanol. The extracts were filtered, evaporated to dryness under reduced pressure on a rotary evaporator and dissolved in dimethyl sulfoxide (DMSO) to the final concentration of $6 \mathrm{mg} / \mathrm{mL}$. All extracts were stored at $+4^{\circ} \mathrm{C}$ until use.

\section{Determination of total phenolic content}

The modified Folin-Ciocalteu method was used to determine the total phenolic content of the extracts (Singleton and Rossi, 1965). Folin-Ciocalteu reagent $(1.0 \mathrm{~mL})$ was reacted with $0.2 \mathrm{~mL}$ of diluted sample, and then $0.8 \mathrm{~mL}$ saturated sodium carbonate solution was added into the reaction mixture. After 30 minutes, the absorbance of the mixture was measured using the UVVis spectrophotometer at $765 \mathrm{~nm}$. The total phenolic contents were determined from the standard curve prepared with gallic acid and the content of total phenolic compounds are expressed as gallic acid equivalents (mg $\mathrm{GAE} / \mathrm{g})$.

\section{Determination of total flavonoid content}

The Dowd method, which is based on the reaction between flavonoids and $\mathrm{AlCl}_{3}$, was used to determine the total flavonoid content in the plant extracts (Dowd, 1959). The diluted extract solution $(0.5 \mathrm{~mL})$ was mixed with $2 \% \mathrm{AlCl}_{3}(0.5 \mathrm{~mL})$. After standing for 10 minutes at room temperature the absorbance was measured at 415 nm. Total flavonoid content of the extracts was calculated from the regression equation of the quercetin calibration curve, and the results were expressed as quercetin equivalents (mg QE/g).

\section{Acetylcholinesterase inhibition}

The tests were conducted based on the Ellman's spectrophotometric method with slight modification (Ellman et al., 1961). Galantamine was applied as the standard compound. In a $1.5 \mathrm{~mL}$ cuvette, $0.1 \mathrm{~mL}$ of sodium phosphate buffer (100 mM, pH 8), $0.1 \mathrm{~mL}$ of sample, and $0.1 \mathrm{~mL}$ AChE solution containing 0.54 $\mathrm{U} / \mathrm{mL}$, were mixed and allowed to incubate for $15 \mathrm{~min}$ at $37^{\circ} \mathrm{C}$. After that, $0.1 \mathrm{~mL}$ of a solution of acetylcholine iodide $(15 \mathrm{mM})$ and $0.5 \mathrm{~mL}$ of $3 \mathrm{mM}$ Ellman's reagent were added and the absorbance at $405 \mathrm{~nm}$ was read after 5 min of the reaction. The percentage of AChE inhibition was calculated based on the absorbance value as follows:

$$
\% \text { Inhibition }=\left(1-A_{\mathrm{t}} / A_{0}\right) \times 100
$$

where $A_{0}$ is the absorbance of the control and $A_{\mathrm{t}}$ is the absorbance of the tested plant extract. The $I C_{50}$ value was determined by non-linear regression of the log inhibitor concentration versus the percentage of inhibition.

\section{Evaluation of antioxidant activity against $\mathrm{DPPH}^{\bullet}$}

The antioxidant activity of analyzed extracts was determined by 2,2-diphenyl-1-picrylhydrazyl (DPPH) method (Blois, 1958). An aliquot of plant extracts (0.1 $\mathrm{mL})$ was added to the $\mathrm{DPPH}^{\circ}$ solution $(1 \mathrm{~mL}, 55 \mathrm{mM})$ and left to stand in the dark at room temperature for 30 min. After that, the absorbance of each mixture was measured at $517 \mathrm{~nm}$. The ability to scavenge the DPPH radical was calculated using the following equation:

$$
\% D P P H^{*}=\left(1-A_{t} / A_{0}\right) \times 100
$$

where $A_{0}$ is the absorbance of the control and $A_{\mathrm{t}}$ is the absorbance of the tested plant extract. The results are expressed as $\mathrm{mg} / \mathrm{mL}$ of plant extract needed to reduce DPPH radical signal by $50 \%\left(I C_{50}\right)$.

\section{Evaluation of antioxidant activity against ABTS ${ }^{++}$}

The 2,2'-azinobis(3-ethylbenzothiazoline-6-sulphonic acid) radical cation $\left(\mathrm{ABTS}^{\circ+}\right.$ ) was prepared by mixing 7 $\mathrm{mM}$ ABTS stock solution with $2.45 \mathrm{mM}$ potassium persulfate and allowing the mixture to react in a dark at room temperature over night (Re et al., 1999). Different concentrations of the plant extracts $(0.1 \mathrm{~mL})$ were mixed to $1 \mathrm{~mL} \mathrm{ABTS}^{*+}$ solution. After mixing and incubating at room temperature for $7 \mathrm{~min}$, the absorbance was recorded at $734 \mathrm{~nm}$. The ability to scavenge the $\mathrm{ABTS}^{\circ+}$ was calculated using the following equation:

$$
\% \text { ABTS }^{\circ+}=\left(1-A_{t} / A_{0}\right) \times 100
$$


where $A_{0}$ is the absorbance of the control and $A_{\mathrm{t}}$ is the absorbance of the tested plant extract. From the percentage of the scavenging activity at different tested extracts concentrations, $I C_{50}$ values were calculated.

\section{Antimicrobial assays}

For the investigation of potential antimicrobial activity of three Cotoneaster species extracts, the following Gram-negative and Gram-positive bacteria, as well as fungi were tested: Salmonella enterica serovar Enteritidis ATCC 31194, Pseudomonas aeruginosa ATCC 9027, Escherichia coli ATCC 25922, Extended Spectrum Beta-Lactamase producing E. coli or ESBL E. coli ATCC 35218, Enterococcus faecalis ATCC 29212, Staphylococcus aureus ATCC 25923, Methicillinresistant Staphylococcus aureus or MRSA ATCC 33591, Bacillus subtilis ATCC 6633 and Candida albicans ATCC 1023. Antimicrobial effects were evaluated through the agar well diffusion method (Balouiri, Sadiki and Ibnsouda, 2016). Standard antibiotic Ampicillin (10 $\mathrm{gg}$; HiMedia Laboratories Pvt.Ltd., India) and antimycotic Nystatin (100 units; Oxoid Ltd., England) were used as positive controls, while DMSO was used as solvent control. Tested microbial species were cultured overnight at $37^{\circ} \mathrm{C}$, in Mueller Hinton medium and Sabouraund Glucose Agar (Fluka Biochemica; Buchs, Switzerland). Inoculums were diluted in sterile saline solution and adjusted to the final density of 0.5 McFarland standard $\left(\sim 1.5 \times 10^{8} \mathrm{CFU} / \mathrm{mL}\right)$, according to Wayne (2007). In order to achieve a total absorption, after the spreading of inoculums over the plates, they are left for 15 minutes at ambient temperature. Investigated extracts and controls $(100 \mu \mathrm{L})$ were transferred into the wells of inoculated plates and incubated for 18-24 hours at $37^{\circ} \mathrm{C}$, and $24-48$ hours at $37^{\circ} \mathrm{C}$, for bacteria and fungi respectively.

Antimicrobial activity of investigated Cotoneaster extracts was evaluated on the basis of inhibition zones diameter ( $\mathrm{mm})$, which is the result of extract diffusion in the medium and inhibition of microbial growth.

\section{Statistical analysis}

All tests were performed in three replications and the mean values \pm standard deviation (SD) were calculated. Descriptive statistical analyses were carried out by Microsoft Office 2013 Excel (Microsoft Corporation, Redmond, USA). Data were further analyzed by using one-way ANOVA and post hoc Newman-Keuls test (STATISTICA 10; StatSoft. Inc.), at the significance level of $p<0.05$.

\section{RESULTS AND DISCUSSION}

Phenolic compounds, which are widely found as secondary metabolites in plants, are known to act as biologically active molecules. Many phenolic compounds, including flavonoids are known to have potent antiviral, anticancer, antioxidant, antibacterial or anti-inflammatory activities (Aziz et al., 1998; Galati and O'Brien, 2004; Kicel et al., 2016). The content of total phenols and flavonoids in the analyzed extracts pointed that these species are rich source of polyphenolic compounds. The amount of total phenolics in extracts ranged between 65.04 and $135.86 \mathrm{mg} \mathrm{GAE} / \mathrm{g}$, while the content of flavonoids ranged from 2.76 to $18.17 \mathrm{mg}$ QE/g (Table 1). The highest content of total phenols and flavonoids was found in the $C$. tomentosus leaf extract,followed by the leaf extract of $C$. integerrimus, $133.54 \mathrm{mg}$ GAE/g and $16.42 \mathrm{mg}$ QE/g respectively, while the corresponding bark extract of $C$.

tomentosus showed the lowest content of total phenolics and flavonoids. It is noticeable that among all analyzed extracts, the content of total phenolic compounds and flavonoids in all samples is higher in the leaves. Results obtained in this study strongly suggest that phenolics are important components of these plants. The one-way ANOVA and Newman-Keuls test showed statistically significant differences in phenolic and flavonoid contents among all tested extracts.

Table 1: Phenolic compounds, antioxidant activity and acetylcholinesterase inhibition of investigated extracts

\begin{tabular}{|c|c|c|c|c|c|}
\hline Sample & $\begin{array}{l}\text { Total phenol content } \\
\text { (mg GAE/g) }\end{array}$ & $\begin{array}{c}\text { Total flavonoid } \\
\text { content (mg QE/g) }\end{array}$ & $\begin{array}{l}\text { DPPH - IC } \\
(\mathrm{mg} / \mathrm{mL})\end{array}$ & $\begin{array}{l}\text { ABTS }-I C_{50} \\
(\mathrm{mg} / \mathrm{mL})\end{array}$ & $\begin{array}{c}\mathrm{AChE}-I C_{50} \\
(\mathrm{mg} / \mathrm{mL})\end{array}$ \\
\hline \multicolumn{6}{|l|}{ C. integerrimus } \\
\hline $\mathrm{LE}$ & $133.54 \pm 2.81^{\mathrm{a}}$ & $16.42 \pm 0.35^{b}$ & $1.23 \pm 0.02^{\mathrm{e}}$ & $0.20 \pm 0.01^{\mathrm{e}}$ & $0.88 \pm 0.03^{b}$ \\
\hline $\mathrm{BE}$ & $80.10 \pm 0.41^{\mathrm{d}}$ & $9.38 \pm 0.27^{\mathrm{d}}$ & $2.99 \pm 0.06^{\mathrm{b}}$ & $0.73 \pm 0.02^{\mathrm{b}}$ & n.d. \\
\hline \multicolumn{6}{|l|}{ C. tomentosus } \\
\hline LE & $135.86 \pm 1.29^{\mathrm{a}}$ & $18.17 \pm 0.30^{\mathrm{a}}$ & $1.22 \pm 0.04^{\mathrm{e}}$ & $0.12 \pm 0.01^{\mathrm{f}}$ & $0.73 \pm 0.01^{\mathrm{c}}$ \\
\hline $\mathrm{BE}$ & $65.04 \pm 0.82^{\mathrm{e}}$ & $2.76 \pm 0.20^{f}$ & $3.73 \pm 0.02^{\mathrm{a}}$ & $0.87 \pm 0.03^{\mathrm{a}}$ & $0.35 \pm 0.01^{\mathrm{d}}$ \\
\hline \multicolumn{6}{|l|}{ C. horizontalis } \\
\hline LE & $93.21 \pm 1.61^{b}$ & $10.55 \pm 0.51^{\mathrm{c}}$ & $2.15 \pm 0.03^{\mathrm{d}}$ & $0.38 \pm 0.01^{\mathrm{d}}$ & $0.34 \pm 0.01^{\mathrm{d}}$ \\
\hline $\mathrm{BE}$ & $82.97 \pm 1.57^{c}$ & $8.73 \pm 0.28^{\mathrm{e}}$ & $2.50 \pm 0.03^{c}$ & $0.42 \pm 0.01^{\mathrm{c}}$ & $0.94 \pm 0.03^{\mathrm{a}}$ \\
\hline Positive control & - & - & $0.06 \pm 0.01^{\mathrm{f}}$ & $0.01 \pm 0.00^{\mathrm{g}}$ & $0.11 \pm 0.01^{\mathrm{e}}$ \\
\hline $\begin{array}{l}\text { The results are the } \\
\text { Values in the sam } \\
\text { est. }\end{array}$ & $\begin{array}{l} \pm \mathrm{SD}(n=3) . \mathrm{LE} \\
\text { mn that don't shar }\end{array}$ & $\begin{array}{l}\text { act. } \mathrm{BE}=\mathrm{b} \\
\text { letters, di }\end{array}$ & $\begin{array}{l}\text { ct. n.d. = not } \\
\text { icantly at } p<0\end{array}$ & $\begin{array}{l}\text { ted. } \\
\text { fter post hoc }\end{array}$ & man-Keuls \\
\hline
\end{tabular}

The literature data on the phenolic and flavonoid content of Cotoneaster species are scarce and present highly variable results. The results by Uysal et al. (2016) showed that the total phenol content in the methanolic extract of twigs of $C$. integerrimus is $115.15 \mathrm{mg} \mathrm{GAE} / \mathrm{g}$, while the flavonoid content was $16.29 \mathrm{mg} \mathrm{RE} / \mathrm{g}$. In addition, the study of Mohamed et al. (2012) analysed the aerial parts of $C$. horizontalis for total phenols and flavonoids content 
and obtained $14.00 \mathrm{mg} \mathrm{GA} / \mathrm{g}$ and $6.80 \mathrm{mg} \mathrm{RE} / \mathrm{g}$ respectively. The investigation of antioxidant activity was carried out to assess the ability of extracts of the three Cotoneaster species to scavenge free radicals by the ABTS and DPPH methods (Table 1). The obtained results were presented as $I C_{50}$ values. In the $\mathrm{DPPH}$ method, $I C_{50}$ values of extracts ranged from 1.22 to $3.73 \mathrm{mg} / \mathrm{mL}$, while for the ABTS method values varied from 0.12 to 0.87 $\mathrm{mg} / \mathrm{mL}$. The best antioxidant activity showed the leaf extract of $C$. tomentosus and the lowest activity had the bark extract of the same species. Generally, extracts of leaves had better activity than bark extracts for both methods. Usually, the $I C_{50}$ values for the DPPH method are higher than the value of ABTS (although they are based on the same reaction mechanism), due to possible steric hindrances in the case of DPPH. Also, some substances present in extracts can participate in the inactivation of $\mathrm{DPPH}^{*}$ and $\mathrm{ABTS}^{\cdot+}$ (Bernatonienè et al., 2008). Previous studies are in lack of data on antioxidant activity of Cotoneaster species, and the published results showed divergence to our results (Sokkar et al., 2013; Kicel et al., 2016; Uysal et al., 2016). In addition, inhibition of AChE was investigated (Table 1). The obtained $I C_{50}$ values were varied from 0.34 for the $C$. horizontalis leaf extract to $0.94 \mathrm{mg} / \mathrm{mL}$ for the corresponding bark extract. All extract showed significantly lower inhibition of AChE than galantamine $(0,11 \pm 0.01)$ which was used as a positive control. Nevertheless, the $C$. horizontalis leaf sample showed moderate inhibitory activity $(0.34 \pm 0.01)$ due to the presence of horizontoates $\mathrm{A}-\mathrm{C}$ in this species which showed remarkable activity according to Khan et al. (2014).

The results regarding antimicrobial properties of the studied Cotoneaster leaf and bark extracts indicate that three investigated species exhibit antimicrobial activity against all microorganisms tested (Table 2).

Table 2: Zones of inhibition obtained through the agar well diffusion method

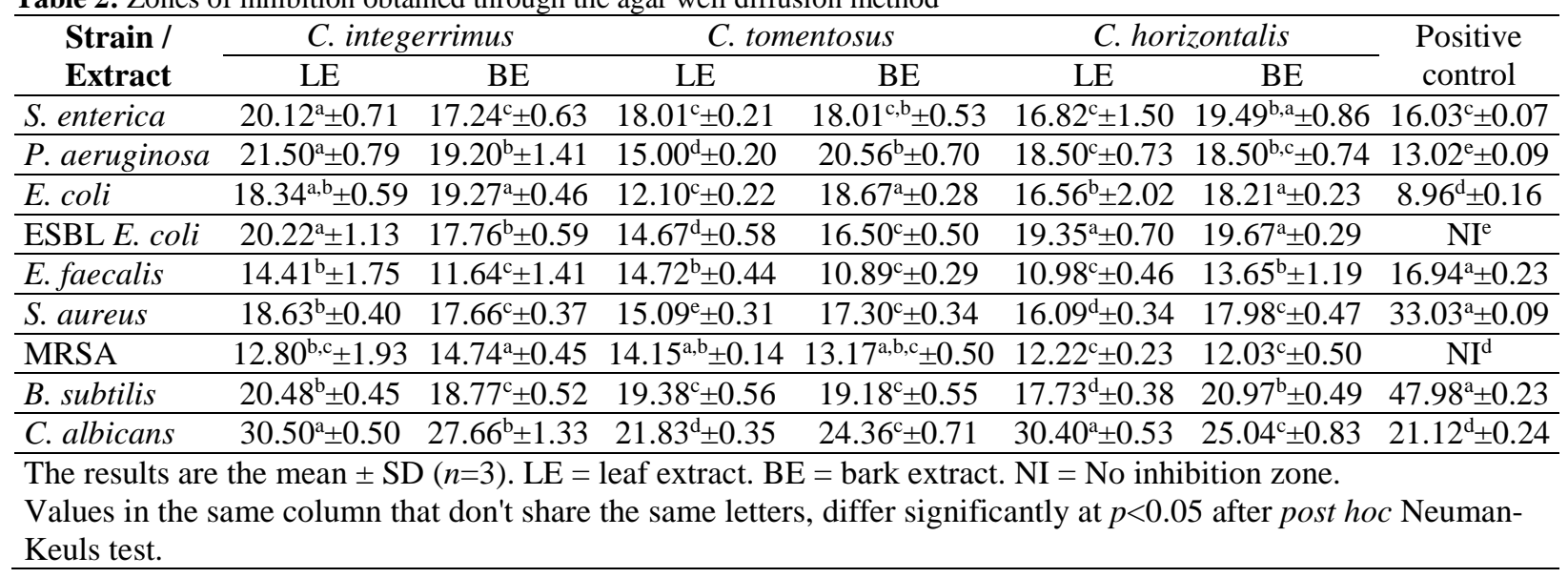

This research showed significantly high inhibition of both Gram-positive and Gram-negative bacteria, as well as fungi, by tested extracts. Largest inhibition zones are noted in case of $C$. albicans, especially with $C$. integerrimus leaf extract $(30.50 \pm 0.50 \mathrm{~mm})$. This plant species caused the greatest zones of inhibition as well as in most investigated bacterial strains (Table 2). According to Uysal et al. (2016), methanolic extracts of $C$. integerrimus have significant antimicrobial potential and their study indicate phenolic components, especially epicatechin, responsible for antimicrobial activity. To our knowledge, this is the first report on antimicrobial properties of $C$. tomentosus. In addition to the antifungal effects observed against $C$. albicans, it is particularly interesting that $C$. tomentosus bark extract caused the greatest inhibition of $P$. aeruginosa growth $(20.56 \pm 0.70$ $\mathrm{mm}$ ), which is known as a versatile pathogen with multidrug-resistance (Hirsch and Tam, 2010). Cotoneaster horizontalis proved to be most effective against $C$. albicans $(30.40 \pm 0.52 \mathrm{~mm})$, followed by $B$. subtilis $(20.97 \pm 0.49 \mathrm{~mm})$ and $P$. aeruginosa $(20.00 \pm 0.74$ $\mathrm{mm})$. According to Mohamed et al. (2012), C. horizontalis is rich in polyphenols, flavonoids, hydrocarbons, phytosterols and different fatty acids, and it contain essential oil with many oxygenated compounds, as well as in phenolic acids (Mohamed et al., 2012; Sytar et al., 2016). Furthermore, this plant species has been recognized as an important source of antioxidative and anticancer compounds such as a-tocopherol and amygdalin (Sokkar et al., 2013). While previous studies have reported the resistance of only some Gram-negative strains to the Cotoneaster extracts (Zengin et al., 2014; Kanaani et al., 2015; Siami et al., 2016), this research showed that all investigated bacteria, including the multidrug-resistant pathogens were sensitive to the methanolic extracts of $C$. integerrimus, $C$. tomentosus and C. horizontalis.

\section{CONCLUSIONS}

This investigation shows that the leaf and bark extracts of three Cotoneaster species collected in Bosnia and Herzegovina possess significant and dose-dependent in vitro antioxidant activity, which positively correlate with their total phenolic content. Based on these facts, it is possible to justify the highest phenolics and flavonoid content for the $C$. tomentosus leaf extract. Different correlations were observed with AChE inhibition results. The $C$. horizontalis sample that showed an average content of total phenols and flavonoids simultaneously 
shows the highest (leaves) and lowest (bark) activity by inhibition. In addition, this study shows a remarkable antimicrobial activity of the tested extracts against both Gram-positive and Gram-negative bacteria, as well as fungi. However, the compounds responsible for the bioactive properties of all three investigated Cotoneaster species remain unclear, so future research should be directed towards solving the detailed chemical composition and isolation of individual bioactive components.

\section{REFERENCES}

Agarwal, P., Agarwal, N., Gupta, R., Gupta, M., Sharma, B. (2016). Antibacterial activity of plants extracts against methicillin-resistant Staphylococcus aureus and vancomycin-resistant Enterococcus faecalis. Journal of Microbial and Biochemical Technology, 8, 404-407.

Aziz, N., Farag, S., Mousa, L., Abo-Zaid, M. (1998). Comparative antibacterial and antifungal effects of some phenolic compounds. Microbios, 93(374), 4354.

Balouiri, M., Sadiki, M., Ibnsouda, S. K. (2016). Methods for in vitro evaluating antimicrobial activity: A review. Journal of Pharmaceutical Analysis, 6(2), 7179.

Beck-Mannagetta, G. (1927). Flora Bosnae, Hercegovinae et regionis Novi Pazar. Srpska Kraljevska Akademija.

Bernatonienė, J., Masteikova, R., Majienè, D., Savickas, A., Kèvelaitis, E., Bernatonienè, R., Dvoráčková, K., Civinskienè, G., Lekas, R., Vitkevičius, K. (2008). Free radical-scavenging activities of Crataegus monogyna extracts. Medicina, 44(9), 706-712.

Blois, M. S. (1958). Antioxidant determinations by the use of a stable free radical. Nature, 181(4617), 1199.

Burden, R. S., Kemp, M. S., Wiltshire, C. W., Owen, J. D. (1984). Isolation and structure determination of cotonefuran, an induced antifungal dibenzofuran from Cotoneaster lactea WW Sm. Perkin Transactions 1,0, 1445-1448.

Chopra, R. N., Nayar, S. L. (1956). Glossary of Indian medicinal plants. Council of Scientific And Industrial Research, New Delhi.

Das, K., Tiwari, R., Shrivastava, D. (2010). Techniques for evaluation of medicinal plant products as antimicrobial agents: current methods and future trends. Journal of Medicinal Plant Research, 4(2), 104-111.

Dowd, L. E. (1959). Spectrophotometric Determination of Quercetin. Analytical Chemistry, 31(7), 1184-1187.

Ellman, G. L., Courtney, K. D., Andres, V., Featherstone, R. M. (1961). A new and rapid colorimetric determination of acetylcholinesterase activity. Biochemical Pharmacology, 7(2), 88-95.

El-Mousallamy, A. M., Hussein, S. A., Merfort, I., Nawwar, M. A. (2000). Unusual phenolic glycosides from Cotoneaster orbicularis. Phytochemistry, 53(6), 699-704.

Euro+Med PlantBase, ww2.bgbm.org/EuroPlusMed (18/07/2019).
Fryer, J., Hylm, B. (2009) Cotoneasters: a comprehensive guide to shrubs for flowers, fruit, and foliage. Timber Press.

Galati, G., O'Brien, P. J. (2004). Potential toxicity of flavonoids and other dietary phenolics: significance for their chemopreventive and anticancer properties. Free Radical Biology and Medicine, 37(3), 287-303.

Hirsch, E. B., Tam, V. H. (2010). Impact of multidrugresistant Pseudomonas aeruginosa infection on patient outcomes. Expert Review of Pharmacoeconomics and Outcomes Research, 10(4), 441-451.

Kanaani, S., Sani, A., Yaghooti, F. (2015). Antibacterial effects and chemical composition of essential oils from Cotoneaster nummularioides Pojark. and Sonchus arvensis L. leaves extracts on typical foodborne pathogens. International Journal of Biosciences, 6(2), 357-365.

Khan, S., Wang, Z., Wang, R., Zhang, L. (2014). Horizontoates A-C: New cholinesterase inhibitors from Cotoneaster horizontalis. Phytochemistry Letters, 10, 204-208.

Khan, S., Yasmeen, S., Afza, N., Malik, A., Iqbal, L., Lateef, M. (2008). Cotonoates A and B, new aromatic esters from Cotoneaster racemiflora. Zeitschrift für Naturforschung B, 63(10), 1219-1222.

Kicel, A., Michel, P., Owczarek, A., Marchelak, A., Żyżelewicz, D., Budryn, G., Oracz, J., Olszewska, M. A. (2016). Phenolic profile and antioxidant potential of leaves from selected Cotoneaster Medik. Species. Molecules, 21(6), 688.

Kokubun, T., Harborne, J. B., Eagles, J., Waterman, P. G. (1995). Dibenzofuran phytoalexins from the sapwood of Cotoneaster acutifolius and five related species. Phytochemistry, 38(1), 57-60.

Mohamed, S. A., Sokkar, N. M., El-Gindi, O., Zeinab, Y., Alfishawy, I. M. (2012). Phytoconstituents investigation, anti-diabetic and anti-dyslipidemic activities of Cotoneaster horizontalis Decne cultivated in Egypt. Life Science Journal, 9, 394-403.

Re, R., Pellegrini, N., Proteggente, A., Pannala, A., Yang, M., Rice-Evans, C. (1999). Antioxidant activity applying an improved ABTS radical cation decolorization assay. Free Radical Biology and Medicine, 26(9-10), 1231-1237.

Romero, C. D., Chopin, S. F., Buck, G., Martinez, E., Garcia, M., Bixby, L. (2005). Antibacterial properties of common herbal remedies of the southwest. Journal of Ethnopharmacology, 99(2), 253-257.

Siami, M., Sani, A. M., Branch, Q. (2016). Antibacterial activity of ethanolic leaf extract from Cotoneaster nummularioides on food borne pathogens. International Journal of Life Sciences, 9(2), 180-184.

Singleton, V. L., Rossi, J. A. (1965). Colorimetry of total phenolics with phosphomolybdic-phosphotungstic acid reagents. American Journal of Enology and Viticulture, 16(3), 144-158.

Sokkar, N., El-Gindi, O., Sayed, S., Mohamed, S., Ali, Z., Alfishawy, I. (2013). Antioxidant, anticancer and hepatoprotective activities of Cotoneaster horizontalis Decne extract as well as $\alpha$-tocopherol and amygdalin production from in vitro culture. Acta Physiologiae Plantarum, 35(8), 2421-2428. 
Sytar, O., Hemmerich, I., Zivcak, M., Rauh, C., Brestic, M. (2016). Comparative analysis of bioactive phenolic compounds composition from 26 medicinal plants. Saudi Journal of Biological Sciences, 25(4), 631-641.

Uysal, A., Zengin, G., Mollica, A., Gunes, E., Locatelli, M., Yilmaz, T., Aktumsek, A. (2016). Chemical and biological insights on Cotoneaster integerrimus: a new (-)-epicatechin source for food and medicinal applications. Phytomedicine, 23(10), 979-988.
Wayne, P. (2007). Performance standards for antimicrobial susceptibility testing. Clinical and laboratory standards institute.

Zengin, G., Uysal, A., Gunes, E., Aktumsek, A. (2014). Survey of phytochemical composition and biological effects of three extracts from a wild plant (Cotoneaster nummularia Fisch. et Mey.): a potential source for functional food ingredients and drug formulations. PLoS One, 9(11), e11352.

\section{Summary/Sažetak}

Iako rod Cotoneaster Medik. obuhvata uglavnom ukrasne vrste, postoje podaci i o njihovom bioaktivnom djelovanju. Cilj ovog istraživanja bio je analizirati sadržaj fenolskih spojeva, inhibiciju acetilholinesteraze, te antioksidativno i antimikrobno djelovanje metanolnih ekstrakata lista i kore vrsta C. integerrimus Medik, C. tomentosus (Aiton) Lindl. i C. horizontalis Decne. Dok ekstrakt lista C. tomentosus ima najveći sadržaj fenolskih spojeva (135.86 mgGAE/g) i flavonoida (18.17 $\mathrm{mgQE} / \mathrm{g}$ ), ali i najznačajniju antioksidativnu aktivnost spram nebiogenih slobodnih radikala, ekstrakt lista C. horizontalis je pokazao najveću inhibitornu aktivnost AChE (IC50 $0.34 \mathrm{mg} / \mathrm{mL})$. Svi ekstrakti su pokazali značajan nivo antibakterijske i antifungalne aktivnosti spram testiranih mikrobnih sojeva. Najveće zone inhibicije su uočene kod vrste Candida albicans tretirane ekstraktom lista $C$. integerrimus $(30.50 \pm 0.50 \mathrm{~mm})$. Nadalje, ekstrakt $C$. integerrimus je bio najučinkovitiji i kod većine testiranih bakterijskih sojeva. Dobijeni rezultati sugerišu da metanolni ekstrakti analiziranih vrsta roda Cotoneaster posjeduju obećavajući bioaktivni i terapeutski potencijal. 